\title{
IOS Mitteilungen
}

No. 65 April 2015

\section{What You See Is What You Get? Images of Central and Eastern Europe in Managerial Discourses since 1990}

Volker Depkat ${ }^{*}$ and Thomas Steger ${ }^{* *}$

\footnotetext{
* University of Regensburg, Department of British and American Studies, Universitätsstr. 31 , 93053 Regensburg, Germany, Phone: +49-941-943 34 76, Email: volker.depkat@ur.de; ${ }^{* *}$ (Corresponding Author), University of Regensburg, Department of Leadership and Organization, Universitätsstr. 31, 93053 Regensburg, Germany, Phone: +49-941-9432681, Email: thomas.steger@ur.de.
} 


\section{tostrosen \\ Südosteuropaforsch
Institute for East and
Southeast European Studies}

Landshuter Straße 4

D-93047 Regensburg

Telefon: (09 41) 94354-10

Telefax: (0941) 94354-27

E-Mail: info@ios-regensburg.de Internet: www.ios-regensburg.de

ISSN: 2363-4898 


\section{Contents}

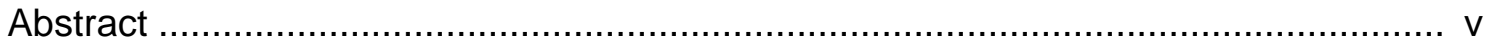

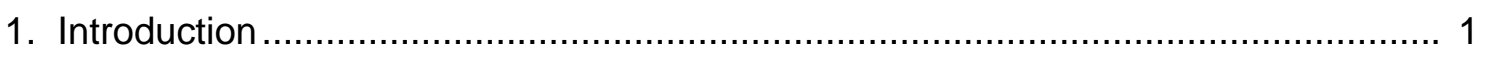

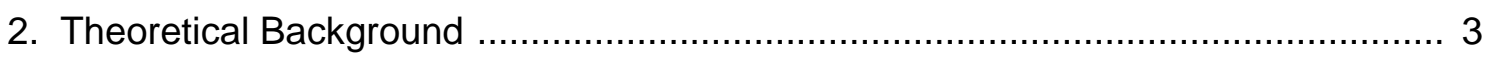

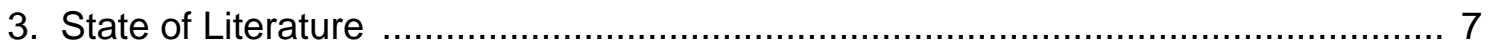

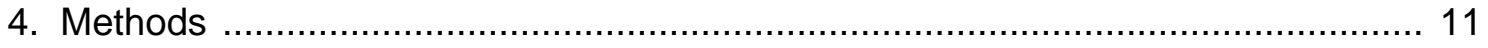

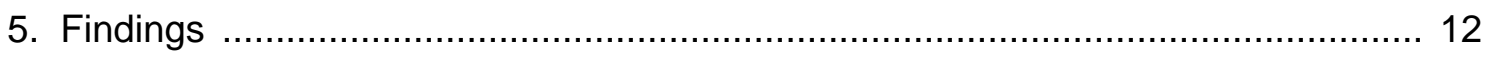

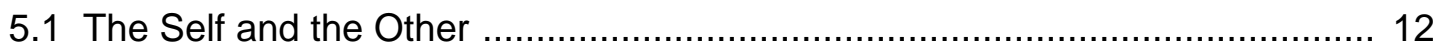

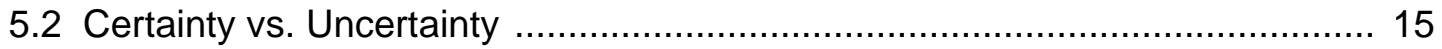

5.3 Universalism vs. Particularism of Practices ............................................ 18

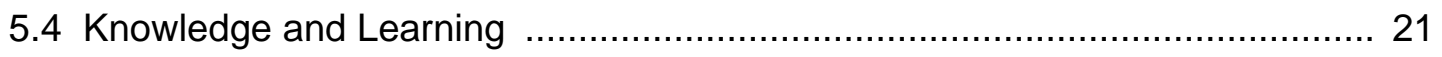

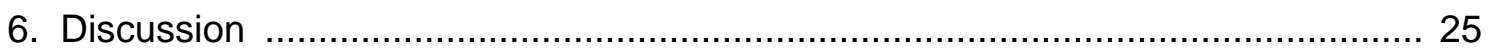

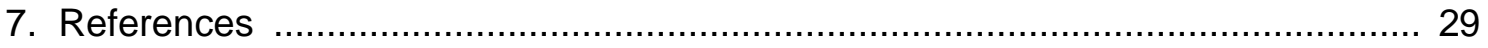

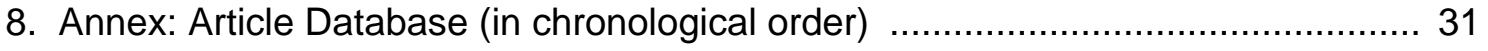

8.1 Academy of Management Executive (17) …....................................... 31

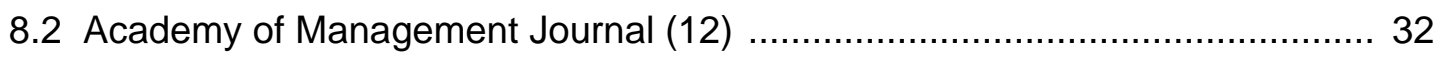

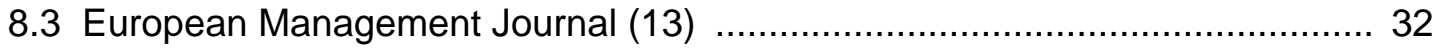




\begin{abstract}
Drawing on a systematic close reading of all relevant articles published in three leading management journals since 1990, the paper analyzes the images of Central and Eastern Europe (CEE) circulating in the business community at the turn of the twenty-first century. It suggests that a mere stocktaking of Western perceptions of 'the East' is not enough, arguing that CEE images in the post-Cold War managerial discourses should be analyzed in both their cultural embeddedness and their epistemological function for the construction of knowledge about CEE. The methodological approach combines a poststructuralist discourse analysis with imagological theories originating in the field of literary criticism to reconstruct the images CEE and investigate into their communicative function in processes of managerial meaning-making and knowledge construction. As such, the paper aims at an analysis of managerial meta-discourses and the very premises and assumptions that generated them.
\end{abstract}

Keywords: managerial discourses, Central and Eastern Europe, publications, management journals 



\section{Introduction}

Upon the collapse of the Soviet Union and its Cold War empire, Western managers started debating the business options opening up in Central and Eastern Europe (CEE) i.e. the former socialist countries of the Eastern 'bloc' in Europe. In trying to assess the possible success of direct investments, joint ventures, and business takeovers, Western business elites reflected the character and direction of the historical transformations underway, described CEE business practices and habits, analyzed the national cultures and characters in this region of the world, and tried to predict the future course of economic developments there. These debates were tied inseparably to the question of how Western corporate leadership and governance could be applied to the transitional economies in the former Eastern bloc, what Western businesses and managers could do to engineer the economic, political and cultural changes there, and what the social responsibility of corporations in this process was.

While these debates were scientific insofar as they moved in the framework of international business (IB) theories, drew on empirical data, and were published in scholarly journals read by the community of academics, they were not exclusively generated from a scientific quest for 'facts' and 'knowledge'. Rather, culturally embedded images and stereotypes about CEE, some of them centuries old, structured, informed and shaped the representation of CEE-realities in these academic journals. At the same time, the representations of CEE-reality were inextricably linked to images of the 'West' and preconceived notions of 'Western identity.' Thus, in debating the economic chances in CEE and defining Western businesses' role(s) in the economic transition process, Western managers were not only constructing outside views on CEE business and management, they were also describing themselves and their own managerial culture in one and the same process. In short, while they were assessing business options in CEE, Western managers were not only constructing a CEE 'other', they were also imagining 'the West' as a coherent cultural entity. In the course of these highly complex communicative processes, theoretical and practical key concepts of Western free-market capitalism like entrepreneurship and competition, incentive and 
accountability, efficiency and quality were taken for granted. The very premises and the cultural embeddedness of IB theory and practices were not problematized.

Drawing on a systematic close reading of all relevant articles published in three leading management journals since 1990 (Academy of Management Executive, Academy of Management Journal, and European Management Journal), the paper analyzes the images of CEE circulating in the business community at the turn of the twenty-first century. Doing so, this paper investigates the following questions:

1. Which images of CEE circulating in the managerial discourses can be identified? What are their central elements? What are recurring patterns in the Western perception of the CEE other?

2. Which concepts and core values of IB theories and practice help generate these images, and which notions of Western business identity are written into the managerial images of CEE?

3. How do these images of CEE serve as arguments for certain business strategies pursued in CEE? How do they inform the business practices of Western companies in the former Eastern bloc?

This paper suggests that a descriptive reconstruction of images of CEE in their content, and a mere stocktaking of Western perceptions of 'the East' is not enough. Rather, it argues that the images should be analyzed in both their cultural embeddedness and their epistemological function for the construction of knowledge about CEE in post-Cold-War managerial worlds. The discursive creation of mental maps and the positioning of CEE on them shaped the way in which Western businesses acted in the post-Cold-War CEE contexts in many respects. By investigating the function of the images of CEE in processes of managerial meaningmaking from 1990 to the present, the paper thus aims at an analysis of managerial meta-discourses and the very premises and assumptions that generated and structured them. 


\section{Theoretical Background}

This paper takes a cultural approach to IB theory and practice, capitalizing on recent theoretical developments inspired by the cultural turn in the humanities (BachmannMedick, 2009; Bogards, 2010; Burke, 2004; Maurer, 2008). The concept of the cultural turn refers to a wide variety of theories, conceptual frameworks and approaches, which are used differently in different academic disciplines for different purposes and to different effects. Yet, as different as they may be, all cultural approaches in one way or another are interested in the genesis and transformation of culturally constructed systems of knowledge and processes of meaning-making that, in providing for orientation vis-á-vis the world, structure social practices and motivate human behavior. As such, many approaches in the field of cultural studies are deeply indebted to a sociology of knowledge and the "social construction of reality" as laid down by Alfred Schütz (1979/1984), Peter Berger and Thomas Luckman (1966).

Not surprisingly, recent cultural approaches have put a great emphasis on social communication as the generator of meaning- and knowledge systems. By social communication we mean that set of communicative practices through which social groups reach an understanding about who they are, and who they want to be, who belongs to them, and who does not, what they hold to be 'good' and 'bad', what they like and what they do not like (Depkat, 2003; Depkat, 2014). These debates emerge from highly controversial and interest-driven quests of social groups to interpret the world they live in as meaningful, which, in turn, is the condition of possibility to act 'meaningfully' in this world in the first place. Cultural approaches, therefore, conceptualize the relationship between knowledge and behavior as being inherently cyclical insofar as socially constructed systems of meaning trigger and motivate certain behavior, while, at the same time, these systems of meaning are the result of time- and culture-specific sets of social practices serving to either stabilize or destabilize the very systems of meaning enveloping them.

There are, of course, many theoretical approaches to the study of social communication, ranging from Niklas Luhmann's systems' theory to Jürgen Habermas’ hermeneutic approach introducing "Lebenswelt" (life world) as a communicative 
paradigm (Luhmann, 1984, 1997; Habermas, 1981). However, to analyze the communicative functions of CEE-images for the construction of knowledge about that world region in the managerial debates since the Cold War, this paper combines critical discourse analysis inspired by the philosophical work of Michel Foucault with imagological theories originating in the field of literary studies.

Discourse analysis, which is widely identified with the work of the poststructuralist philosopher Michel Foucault, is not a method per se but a set of epistemological premises and philosophical concepts that defines how we analyze forms of speech (Foucault, 1969; Foucault, 1971; Howard, 2000; Landwehr, 2009; Mills, 2010; Sarasin, 2003). The approach takes the materiality of language as the point of analytical departure, and proceeds to the institutional, political, social and economic conditions of possibility of concrete statements made in specific historical context. Understanding discourse as an institutionalized form of speech, discourse analysis is interested in the actual use of words on the textual surface, and strives to unearth the order, regularities and rules of language usage, which, however, are not just grammatically defined but also socially, institutionally, and historically.

Discourse analysis is never just interested in one single statement but in the relation of one statement to other statements made and the power-driven social practices that let them surface in the first place. Always starting with the concrete usage of words and other non-verbal signs on the surface level, discourse analysis moves on to reflect individual statements as integral parts of larger discursive constellations as carriers of knowledge of the time. A discourse, therefore, is understood to be a time-specific configuration of interconnected statements, verbal and non-verbal in nature that carries strands of the socially constructed knowledge of a certain social group at a certain time.

In this context, a key issue of discourse analysis is the relationship between knowledge, truth and social power, which is seen to be inherently cyclical. On the one hand, the discourses of a time are understood to be power-driven, which means that knowledge always has a social base, and is, therefore, not removed from the interests, perceptions, and cultural conditioning of the actors involved in a discourse. On the other hand, and this goes way beyond the Marxist Überbau-Unterbau-concept of 
ideology as 'false consciousness' veiling the material base of power relationships, discourses are seen as not only 'mirroring' social power relationships but also as actually producing them by defining what is true and false, what is right and wrong, what is normal and deviant.

As such, a discourse in the eyes of discourse analysts is a social fact in and by itself subordinating the participants in the discourse to its very rules and regularities defining what can be said in a certain context, and, just as important, who can say that. Discourse analysis thus does away with the notion of the autonomous communicative subject, and replaces it with two new categories, i.e. the dispositif and the archive. While the archive is the system of rules and regulations defining the inner order of a discourse, the dispositif is the apparatus of institutional, physical and administrative mechanisms that connects the various actors and elements to form a discourse. Foucault defines the dispositif as a

"thoroughly heterogeneous ensemble consisting of discourses, institutions, architectural forms, regulatory decisions, laws, administrative measures, scientific statements, philosophical, moral and philanthropic propositions - in short, the said as much as the unsaid. [...] The apparatus itself is the system of relations that can be established between these elements.” (Foucault, 1980: 194).

Continuously interacting, archive and dispositif regulate what can and what cannot be said at a given time in a certain politico-social context. A discourse analysis centering in the categories of archive and dispositif, therefore, will not primarily be interested in the content and the subjective meaning of statements and their relationship to some outer reality but rather analyze the surfacing of statements in a certain place at a given time in their regularity and power-driven historical condition of possibility.

Discourse analysis opens up a new take on the analysis of images about other countries and cultures. It suggests that they should no longer be primarily analyzed in terms of how 'realistic' they are, i.e. how much they are in keeping with the 'realities' in the countries and culture they describe. While this does not mean that one should stop asking these questions altogether, discourse analysis encourages us to take the study of images further to identify their communicate function for the social 
construction of reality. This paper, therefore, suggests complementing discourse analysis with imagolocial approaches from the field of literary criticism. Literary imagology as pioneered by Hugo Dyserinck, Manfred S. Fischer, Waldemar Zacharasiewicz, and others, has moved well beyond the descriptive reconstruction of how members of one culture perceived other countries, regions and peoples (Beller, Agazzi, \& Calzoni, 2006; Dukić, 2012; Fischer, 1981; Zacharasiewicz 2010). Rather, they are systematically asking for the notions of the self not only written into but also constructed by the very representation of other countries, regions and peoples. Imagological approaches thus center in the premise that notions of the 'self' are always dependent on the construction of 'significant others' that are 'significant' insofar as they in one way or another serve to construct and uphold one's sense of identity. In sum, this suggests that images of other countries, regions, cultures and peoples are hardly ever disinterested representations of reality as it actually is but rather culturally conditioned and interest driven discursive constructions that serve identity-purposes.

Analyzing images of CEE in the managerial discourses from 1990 to the present thus encourages self-reflection about the very premises that shaped Western business perspectives on CEE in the post-Cold War world. It asks for the (cultural) condition of possibility of corporate leadership, governance and corporate social responsibility in the CEE contexts and it contributes to reaching a greater clarity about the situation businesses and managers were and are acting in. This selfreflexive clarity, in turn, seems to be the precondition for improving processes of corporate decision-making. 


\section{State of Literature}

The paper contributes to the problem of management in the transitional economies of $\mathrm{CEE}$, which has generated a considerable number of scholarly publications. We note the special issues or symposia of prestigious journals dedicated to this topic (e.g., International Studies of Management and Organization, Organization Studies, European Management Journal, Academy of Management Journal, Journal of International Business Studies, and Journal of Management Studies). Furthermore, numerous edited volumes, books, and book series by prominent publishers (e.g. Ashgate, Edgar Elgar, Palgrave) have been issued. Last but not least, a few journals with particular focus on CEE countries or management issues in emerging economies were founded, such as Journal of East-West Business (1995), Journal of East European Management Studies (1996), and Baltic Journal of Management (2006).

It is not surprising, therefore, that several authors have reflected upon and have tried to summarize the research output in this field: In a rather early review, Banaj (1994) concluded that US scholars were dominant in the field. Interestingly, this finding has remained widely undisputed and hardly explored in the following years. Alt and Lang (2004) have basically confirmed this finding in their (particular) review on research about East Germany. Gelbuda, Meyer and Delios (2008) mentioned that researchers with a CEE heritage increasingly participated in international academic discourses and, thus, have contributed to a merger of (local) context knowledge and (Western) methodological know-how. Steger and Lang (2011) confirmed this but, at the same time, highlighted the endurance of Western, particularly US, dominance in the field.

With respect to theoretical and paradigmatic fundaments, Hoskisson, Eden, Lau, and Wright (2000) argued that institutional theory has first become most relevant when markets emerged. As markets matured, transaction cost economics and, subsequently, the resource-based view of the firm gained in importance. Meyer and Peng (2005), exploring 218 articles from 13 top journals, found that CEE research had particularly highlighted the importance of contextual influences and detected the limitations of classic organizational economics theories in a highly volatile environment to which several of their assumptions do not apply. Wright, Filatotchev, 
Hoskisson, and Peng (2005) also found institutional theory to have been most dominant although usually blended with transaction cost economics, resource-based view, or agency theory. Soulsby and Clark (2007) argued that particularly higher context approaches such as comparative institutionalism, organizational learning, and organizational change could have made some major contributions to organization theory and, the other way round, were enriched by more finely grained research in the field. Gelbuda, Meyer and Delios (2008) also identified that scholarly studies about CEE management problems increasingly employed institutional perspectives, namely institutional economics and sociology-grounded institutional theory. This was also stressed in the review by Puffer and McCarthy (2011) that explicitly claimed to use "an institutional theory perspective”.

Regarding the topics explored in CEE management research, Banaj (1994) mentioned that the penetration and settlement of foreign firms in CEE and the HRM methods used in those countries seemed to be the most attractive topics (in the early years). Wright, Filatotchev, Hoskisson, and Peng (2005), who particularly focused on strategy research, found that scholars were mostly interested in firms from developed economies entering emerging economies and domestic firms competing within emerging economies, while strategies of firms from emerging economies entering other emerging economies or entering developed economies were not analyzed with the same intensity. Taking a more general view, Steger and Lang (2011) stated organizational change, followed by corporate strategy, managerial behavior, and HRM, to be the most widely explored topic throughout the time since 1990.

Those reviews, indeed, need to be critically re-considered with respect to our topic: Some authors (e.g. Puffer \& McCarthy, 2011) have predominantly summarized the contents of Russian business and management research without going any deeper into the studies examined. Among those, who have taken a closer look at the studies, the number of theoretical aspects and theories examined remained limited and some considerations in this respect were rather normative than descriptive (e.g. Hoskisson et al., 2000). Methodological and methodical aspects of management research were hardly discussed and the importance of the role of scientific paradigms has been widely ignored. With one exception (Meyer \& Peng, 2005), the reviews did neither cover a 
systematic analysis of a major sample of publications in the field nor did they examine in more detail the developments throughout the years. Moreover, the authors of those reviews often refused to take a critical position towards the production process of scientific knowledge. Against this backdrop, it hardly comes as a surprise that the presence and function of images, stereotypes and culturally conditioned outside perspectives on CEE have not yet been reflected as factors of knowledge production by practitioners in the field of in IB theory and practice.

Obviously, it is necessary to broaden our focus here, i.e. to look at the findings of scholars from non-management disciplines: The study of perceptions and representations of foreign countries, nations, cultures and regions is a classic topic of intellectual history and literary studies that has generated a multitude of monographs and articles so great that we cannot document it here (for a bibliographical systematization cf. Hoffmann 1986, 2008). Even if we narrow it down to CEE countries, there are numerous studies dealing with the images of Russia, Poland, Hungary and other CEE countries of individual authors, travelers, and intellectuals from different European and non-European countries. In addition, the images of CEE countries in foreign media and public opinion have been investigated into for different countries and historical periods. There are, however, only few studies that systematically analyze Western perceptions of post-Communist CEE. If we just take German images of Russia at the turn of the 21st century, the studies of Antonina Zykova, Varvarra Degtjarova, Stella Gavrilova, and Katrin Seifert have analyzed the representation and construction of Russia in the newspapers and television (Zykova 2014; Degtjarova 2007; Gavrilova 2005; Seifert 2003). Furthermore, some collected volumes of a more general nature, thematizing different aspects of the images of Russia currently circulating in Germany have been published (Lobkowicz 2008; Krumm, Medvedev \& Schröder 2012). A similar situation can be assessed for images of other CEE countries in Germany and other Western European countries. The classical text genres analyzed in this context, however, are travel accounts and literary texts, newspaper and magazine articles or television broadcasts. Nobody in the field of cultural studies and literary criticism has looked at the images of CEE countries circulating in managerial discourses so far. 
All of the above suggests that further research focusing on the role of perceptions and stereotypes in intercultural encounters and the problem of intercultural learning is obviously needed in order to gain more intimate knowledge about how management research on CEE countries has developed throughout the past two decades, and what this has meant for corporate leadership, governance and CSR. 


\section{Methods}

Drawing on a systematic close reading of all relevant articles (42) published in three leading management journals since 1990 (Academy of Management Executive, Academy of Management Journal, and European Management Journal - see complete list of articles in the annex), the paper analyzes the images of Central and Eastern Europe circulating in the business community at the turn of the twenty-first century and their relevance for corporate leadership, governance and CSR in the very CEE context. It tries to identify their central elements and recurring patterns, investigates their communicative functions in the larger identity-defining discourses of the day, and unearths the key concepts of IB theory and practice written into the scenarios about CEE and its future.

In dealing with the articles closely read, we have (a) systematically identified metaphors used to represent and frame the situation in CEE, (b) reconstructed the discursive interconnectedness of individual statements about CEE 'realities' to distil the strands of the major narratives on CEE, and (c) traced the narratives identified to the core values and key concepts of IB theory that generated and shaped these discourses in the first place. In all, therefore, we have excavated the subtexts underneath the surface level of the scholarly articles, always asking what else Western managers were talking about when they were talking about CEE. The overall approach, therefore, is to reconstruct the communicative function of the images by way of "thick description" (Geertz, 1973) and discursive contextualization of individual statements.

As such, the approach of the paper is thoroughly interdisciplinary as it joins two scholars from different disciplines together: The first author is a trained historian and professor of American Studies, who has done a lot of work on the perception of the United States in Europe and on problems of cultural transfer. The second author holds the chair in the area of management. His research interests mainly focus on corporate governance and management issues, particularly in the transitioning countries of CEE. 


\section{Findings}

Our analysis results in four major patterns that characterize the very nature of management research about CEE throughout the past two and a half decades. Hereafter, we describe each pattern in more detail and illustrate them with some concrete quotes from the articles explored.

\subsection{The Self and the Other}

The managerial discourses analyzed tend to construct CEE as a cultural entity, the very unity of which being defined by a shared Communist past. Written into this construction of $\mathrm{CEE}$ as a coherent, even monolithic culture area originating in the Communist experience is a concept of the West as a community of values forged by natural rights individualism, liberal democracy, and free-market capitalism. As a result, the mental maps discursively drawn in the managerial debates are structured by binary oppositions centering in 'us-versus-them'-patterns that identify 'the West' and CEE as two distinct culture areas with two mutually exclusive ways of life. As Ivancevich, DeFrank, and Gregory (1992) write,

"[a] people who have lived through the icon, axe, hammer, and sickle, will have difficulty and frustration adjusting to a world of democracy, free enterprise, and risk-taking decision making.” (Ivancevich, DeFrank, \& Gregory, 1992: 54)

The concept of CEE culture transported in these discourses appears as rather holistic. 'Irresponsibility,' 'collectivism,' 'inactivity.' and 'stasis' are represented as the dominant attitudes of CEE ways of life. The notion of CEE culture being "collectivist" surfaces time and again in the articles we have analyzed (Bruton \& Rubanik, 1997: 73; May, Stewart, \& Sweo, 2000: 420; Mueller \& Clarke, 1998: 326), and this formula of collectivism serves to explain the phenomena, behavioral patterns and business practices that Western managers encounter in CEE countries. Mueller \& Clarke (1998: 322) thus speak of a "sociopolitical environment" in post-Communist Russia "that subordinates individual interests to the collective welfare”. Explicitly tracing the "collectivistic culture” in Eastern Europe to the historical experience of Socialism, they highlight that 
"people in the Central and Eastern European countries tended to be more socially or externally oriented, and that those in the United States and other Western countries tended to be more individually or internally oriented.” (Mueller \& Clarke, 1998: 322)

In a larger context, this difference between CEE collectivism and Western individualism is frequently based on a conceptual framework that links 'traditionalism', 'backwardness' and 'irrationality' to Central and Eastern Europe, while it defines 'the West' as 'modern', 'progressive' and 'rational'. This mental map surfaces in all desirable clarity in Snejina Michailova's article entitled “Contrasts in Culture: Russian and Western Perspectives on Organizational Change,” in which she writes:

"Whereas efficiency, predictability, professionalism, and modernity are seen as key forces for rationality in the West, belief in fate and destiny reflect an underlying faith in the Russian context. While a professionally oriented and modern Western society provides little room for traditions and regards them as slowing down progress, Russians tend to value them very highly. They perceive the future orientation and focus on action and achievement in the Western context as not very appropriate, and admire history and traditions instead.” (Michailova, 2000: 106)

Inseparably connected to the binary opposition of the 'us-versus-them,' is a deficitdiscourse that reflects CEE business cultures in terms of what they lack in light of Western standards. The topical scope of these deficiency-statements is wide and varied, ranging from institutional and political circumstances to mentalities and culturally forged predispositions.

"In Central and Eastern Europe, privatization is challenged by the absence of efficient capital markets, and a lack of entrepreneurial and managerial skills” (Uhlenbruck \& de Castro, 2000: 381).

May et al. (2000) stress that

"Bulgarian managers underutilized certain information resources because they lacked the knowledge necessary to handle complex business documentation and management information systems” (May et al., 2000: 407). 
Meanwhile Earle, Spicer, and Peter (2010) argue that

"one factor in the spread of wage arrears in the Russian case was likely the relative lack of labor mobility across communities, which limited the opportunities of Russian workers to escape deviant organizational practices.” (Earle et al., 2010: 234)

Hitt, Dacin, Levitas, Arregle, and Borza (2000: 463), finally, see the "the lack of financial capital and the lack of infrastructure to provide access to capital" as a "major deficit" in Poland and Romania. From these multi-layered deficit discourses result the many suggestions for what needs to be done to help CEE economies. Shama (1993), for example, sees the necessary development in CEE countries leading

"from little or no competition to more competition; from little or no management control over marketing mix decisions to more control of such decisions; from little planning to more planning” (Shama, 1993: 24).

The effect of this discourse on deficits, which implicitly sets the Western businesses practices as a norm and takes them for granted, is to frame the encounter between Western management and CEE business practices in terms of a "clash of cultures.” This discourse produces some very strong metaphors, suggesting that

"[m]ost of the managerial values developed during the Soviet period, and their attendant attitudes and behaviors" were "antithetical to Western management practices” (May, Puffer, \& McCarthy, 2005: 26).

Against this backdrop, it becomes clear why the transfer of Western knowledge to CEE countries is sometimes described as a "battle of wills" or a "mental combat" (May et al., 2005: 33)

Only rather slowly some 'shades of grey' are identified, with some authors starting to become aware of the cultural and historical diversity within the supposedly monolithic sphere of Central and Eastern Europe. McNulty (1992: 80) thus speaks of "Eastern Europe's many cultures”, while Luthans and Riolli (1997) state that

"each of the former Communist countries is quite different, and the reasons for the successes and failures are varied and complex, involving historical, cultural, political and even geographical issues” (Luthans \& Riolli, 1997: 71). 
However, these voices stressing the diversity within CEE are rather marginal in the debates we have looked at for this paper. This has something to do with the overall lack of knowledge and understanding of the situations, contexts, and processes in post-cold war CEE. Stating this relative ignorance about Central and Eastern Europe, interestingly enough, is one of the formative factors of the managerial discourses on CEE.

"The world in general and Western scholars and managers specifically know very little about Soviet management styles.” (Ivancevich et al., 1992: 43)

Shama even states that "[o]ur knowledge of management behavior during this transformation is scant and anecdotal" (Shama, 1993: 23). This admission of ignorance, however, is conceptually linked to the construction of CEE as a cultural entity forged by the experience of Socialism, which lets CEE not only appear as a 'different' but as a 'foreign,' and even 'exotic' world that Western managers seem to entering as 'intruders from a different planet'.

\subsection{Certainty vs. Uncertainty}

Another major discursive strand in the articles read is a complex relationship of certainty and uncertainty. Most authors thematize multitude of aspects about CEErealities, in which a ubiquitous ambiguity and insecurity about the present and the past in CEE becomes manifest.

Initially, and particularly in the articles of the early 1990s, the changes in CEE were perceived as tumultuous and disruptive, even as unbelievable and indescribable. Usually, people in similar situations tend to use metaphors to express what they have in mind but cannot express in 'dry' language (Geertz, 1973). This is well visible in many articles of that time. Pearce (1991: 77) conjures up the image of an "avalanche of change” in CEE, while Shaw, Fisher, and Randolph (1991: 11) argue that “worlds have been turned upside down" (Shaw et al. 1991: 11). Even several years later, Luthans and Riolli (1997) tried to describe what they have seen and experienced in Albania not with some abstract facts and figures but with the help of an image reminiscent of an auto graveyard. 
"[Communism in Albania] has been ripped down, broken into bits and carted away. This ravaged country is recycling itself out of the rubble.” (Luthans \& Riolli, 1997: 61)

At the same time, this representation of the past and present changes as disruptive and beyond control is inseparably linked to some explicit certainties derived from supposed historical necessities and economic rules ('natural laws'). Betraying an essentially deterministic approach to a historically open situation, Western managers assumed that certain developments would take place more or less automatically.

“[C]ompetitive pressures compel firms to produce goods at higher quality levels” (Forker, 1991: 71).

"As the economic system matures it is expected that the connection between ownership and management of the firm will change manager's attitudes toward workers and excessive staffing” (Bruton \& Rubanik, 1997: 73).

In a situation of widespread uncertainty and openness this determinism provided both authors and readers with orientation, a 'red line' so to speak that guaranteed to turn an open-ended transformation into a more clearly defined transition process with a clear target or final state. It is taken-for-granted by almost all authors that this 'end of history' cannot be anything but free-market capitalism in a liberal democracy. This becomes obvious in the managerial treatment of those CEE countries that have supposedly already started to go exactly this way.

"Czechoslovakia, Hungary, and Poland have been using drastic means to move their countries from planned political and economic systems into systems of political democracy and market economy.” (Shama, 1993: 25)

Moreover, this strict determinism eliminated the (potential) fear of a return to Socialism that existed even among experts at that time, in particular after the revolt of the 'old guards' in the Soviet Union in the summer of 1991. As Ivancevich et al. (1992: 45) put it, "there is no way for the Soviet Union to turn back. This is important."

In all, therefore, while the managerial discourses betrayed a sense of uncertainty about what was going on in CEE, they were at the same time certain that the final outcome of the changes underway was free-market capitalism and liberal democracy. To reach this 'final state' of history, many authors advocated substantial market reforms in a short 
period of time, which was time and again framed in terms of "shock therapy". Accordingly, the necessity for many different key measures (e.g., privatization) to support and secure this process is stated time and again. This concerns in particular the large range of political, legal, social and economic reforms that should encourage the introduction and stabilization of capitalistic institutions and practices that in and by themselves are perceived as being without any alternative. To quote again Ivancevich et al. (1992):

"As suggested throughout this article, management must be motivated and enthusiastic about leading the way to competitive free market transactions.” (Ivancevich et al., 1992: 45)

"When and if ... managers are given more opportunities to develop trade relationships, set prices, and plan their production work, the Soviet system can begin competing in the world-market place.” (Ivancevich et al., 1992: 51)

Next to this, and even a bit less taken-for-granted, there are several actions and activities that are normatively postulated and set as indispensable. Here, we also find several 'soft' measures such as developing new products or learning new skills that are assumed to be necessary under the new conditions.

“[T]here is a long-term need in Russia for deep restructuring, involving enhanced management skills, extensive capital investment, and new product development” (Wright, Hoskission, Filatotchev, \& Buck, 1998: 75)

Yet, the changes experienced during the 1990s and early 2000s shattered many expectations and hopes, which produced a high pressure to legitimate Western standpoints 'after the fact'. In light of empirical evidence from CEE, Western managers had to admit that the nature of many processes had not turned out to be automatisms but that they had numerous 'unintended consequences' leading to new problems and hardships. These very observations and experiences had the potential to seriously question the initial optimistic expectations regarding the reliability of reforms, the stability of the new political and economic contexts, and the profitability of joint ventures and direct investments, and the very premises and convictions they were based on. As Wright et al. (1998) sadly put it:

\footnotetext{
"Reformers hoped that the replacement of the state with private owners would introduce improved structures of corporate governance, which would, in turn, generate new strategies
} 
resulting in improved performance (...) [however] any restructuring has often been passive, involving little managerial initiative and much inertia” (Wright et al., 1998: 76, 82)

What was the discursive reaction to this disappointment? The debates did not question the fundamental concepts and assumptions of IB theory but started to explain the unexplainable by stressing other reasons for the unexpected turn of events in CEE countries. In this context, the cultural predispositions and behavioral patterns of CEE cultures were blamed. What Wright et al. (1998) only hinted at in their quote above was made more explicit by other authors.

"The inertia of SOEs and the associated mentality of managers have been difficult to overcome even after privatization.” (Rondinelli \& Black, 2000: 87)

"After a period of training, Polish employees in French hypermarkets were expected to have acquired Western attitudes", but "[t]he Poles did not seem ready to learn the knowledge the French had come to transfer.” (Hurt \& Hurt, 2005: 38)

These behavioral patterns blocking and hampering the capitalist transformations in CEE are frequently identified as being centuries old traditions, so that, in the end, the determinism of culture turns out to be even stronger than the determinism of the 'natural laws' described above.

“[M]any barriers to knowledge transfer can be attributed to specific aspects of Russian culture, values, attitudes, and behaviors that affect managerial practices.” (May et al., 2005: 25)

Thus, in reflecting about what went wrong in CEE, Western managers actually cemented their certainties and convictions instead of rethinking them, which is why the discourses on certainty and uncertainty can be considered an illustrative example for the power of a scholarly paradigm that, once entrenched and hegemonial, is hard if not impossible to change or modify even in light of empirical evidence.

\subsection{Universalism vs. Particularism of Practices}

A complex tension between the proclaimed universalism of Western entrepreneurial practices and their only limited applicability to CEE is one of the driving moments of the managerial discourses we have investigated. In this context, the deficit-discourse on CEE business culture as reconstructed above is to a large extent shaped by a normative 
ideal of Western entrepreneurship held to be universal, and, thus, apt to work as a role model for CEE managers on their way to free-market capitalism.

"Like managers in other Central and Eastern European economies, Hungarian managers at the beginning of the 1990s were also found to be short on initiative and long-term objectives. Managers in the early phase of a transition tend to be undermotivated from working in a culture devoid of profit seeking.” (Steensma, Tihanyi, Lyles, \& Dhanaraj, 2005: 218)

This assessment is not limited to the upper echelons of the business hierarchies but also applied to lower level employees, who likewise show little initiative at their workplace, as Frese, Kring, Soose and Zimpel (1996) drastically describe:

“[S]ecretaries may fail to do a task because they have the wrong telephone number, even though they could obtain the number form another person. Or blue-collar workers may wait next to broken machines until a supervisor comes by, instead of looking for him or her or for a technician who could fix the machines.” (Frese et al., 1996: 37)

These descriptions, moreover, clearly demonstrate that the authors' perceptions are ultimately rooted in the paradigm of modernization theory, i.e. in the strong belief that there is only one development path to free-market capitalism, which the CEE countries have not fully embarked on, if they have embarked on it at all.

"The bankruptcy of the Communist system and the development towards a market economy in Central Europe very quickly led business leaders to assume that Western, globally accepted, and time-tested management practices would be transferred to postsocialist economies as the "one-best-way". Central European firms would simply have to catch up.” (Hurt \& Hurt, 2005: 36)

Being deeply rooted in the modernization paradigm, many voices in the discourse take it for granted that Western concepts and ideas can easily be transferred to CEE on a one-toone basis. Since the Western development is seen as defining the road that CEE countries would have to take, there is little doubt in the managerial discourses that the instruments of ‘Western capitalism' provide the tools for shaping the developments in CEE.

"Although the debate on whether Western management principles and practices are applicable in an alien environment is not new, a substantial number of management 
models implicitly assume that Western management approaches and techniques can easily be transferred across borders.” (Michailova, 2000: 100)

Nevertheless, there are some voices already during the early years of transformation that openly problematized the proclaimed universalism of Western management concepts. On the one hand, these voices argued that the conditions in CEE were too specific and different from the ones in Western countries to allow for a simple transfer of Western management practices to CEE contexts. This goes hand in hand with an increasing awareness of the often only limited applicability of those practices to CEE.

"Believing that all Eastern Europe needs is American-style management is a myth." (McNulty, 1992: 80)

"Our managers must realize that their way of thinking and doing business just do not work in Eastern Europe or any other part of the world. Our methods have to be adapted...” (McNulty, 1992: 87)

On the other hand, several authors refer to the specific cultural embeddedness of those concepts and practices in the West European or North American managerial traditions. To transfer them to what is seen as a completely different cultural setting, they essentially argue, would most probably cause some 'cultural clashes'.

"Given the fact that previous planning focused heavily on physical volumes and engineering concepts of efficiency, the new move to a market money-based economy make costs and profits difficult to understand in many enterprises. Concepts of return on capital are essentially unknown in most of the member companies.” (Taucher, 1992: 170)

At the same time, however, these same discussants try to explain why people and businesses in CEE were performing the way they did, and the answers given draw heavily on cultural determinism, suggesting that commercial failure was a logical, and by no means a surprising result of the unmodified transfer of Western management concepts to a CEE setting. This opened the doors to centuries-old stereotypes about CEE. Although often degrading and even insulting in the eyes of the people concerned, those stereotypes continue to play an important role in the managerial discussions of CEE to this very day. 
"The requirement of profitability is accepted as the new theory but taken no more seriously than Stalin's economics of socialism. Instead of Marx and Lenin the reformed manager is likely to quote from Milton Friedman and Friedrich von Hayek, but in his heart of hearts he expects to 'manage' very much as before - though he would never admit this, not even to himself.” (Hermann \& Hermann, 1990: 288)

"The environment in Russia and Central and Eastern European countries is often described as traditionally hostile to entrepreneurial activities; in Russia, it was aversive as far back as the tsarist era” (Puffer \& McCarthy, 2001: 29)

This resort to cultural determinism in the quest to explain, why supposedly universal management concepts and practices did not work that well in CEE, prevents a critical questioning of the concepts themselves and the very premises they are based on. It is not the concepts that are wrong but rather the cultural environment of CEE that prevents Central and Eastern Europeans from appreciating them.

\subsection{Knowledge and Learning}

Against the backdrop of the widespread assumption that the developments in CEE after 1989 were a historically necessary movement towards free-market capitalism and democracy, the debate about knowledge and a multitude of different learning/unlearning activities makes a major part of the managerial discourses. Just to give two striking examples here:

"[T]he East German system of education and management organisation produced managers unable to meet the new demands of a market economy in either the old East or West Germany.” (Randlesome, 1992: 74)

"[M]ost managers were not starting with a tabula rasa, to accomplish real change they had to go through a process of unfreezing the elements in their backgrounds that inhibited receptivity to learning market-oriented practices.” (May et al., 2005: 25).

In this context, Western businesses conceived of themselves paternalistically as educational agents in transitional CEE economies, teaching 'Western' business practices to a 'foreign', even 'hostile' world. 
"The foreign parent joint-venture relationship can be viewed as a teacher-student relationship” (Steensma et al., 2005: 219).

In this context, the very ability of Western businesses to serve as 'teachers' was mostly taken for granted; the paternalistic attitudes towards CEE among Western businesses and managers did not allow for much doubt whether they would actually be able and ready to teach Central and Eastern Europeans free-market capitalism. Accordingly, the instruments of management education and training are mostly not critically assessed either. On the macro level, privatization, competition and entrepreneurship are perceived as tools to engineer the transition as a kind of a 'shock therapy'. On the micro level, the educational discourses demonstrate only little patience of Western businesses with their CEE-students,

"[t]he trainers found that a combination of carrot and stick was essential to promote action.” (Hurt \& Hurt, 2005: 31),

and there is only little discursive compassion for the CEE-citizens struggling with the hardships produced by the 'shock therapies'.

"The so-called shock therapy policies associated with transition to a market economy have clearly imposed hardships on the citizenry of the Central and Eastern European countries.” (Mueller \& Clarke, 1998: 322)

Interestingly, the managerial discourses constructed CEE as a kind of "laboratory" for the testing of 'Western' theories and concepts, which was to help developing and deepening Western knowledge about engineering change under adverse conditions.

"During the decade of the 1990s, Russia was a veritable laboratory for observing how entrepreneurial behavior can spring up in a country with extremely limited experience in, and a marked disdain for, entrepreneurship.” (Puffer \& McCarthy, 2001: 25)

However, these 'experiments' partly resulted in some highly ambiguous and even irritating experiences from a Western perspective.

"A within-subjects experimental design was used to analyze the impacts that three popular and successful techniques used in U.S. studies had on the performance of workers in the largest textile factory in the Russian republic of the former Soviet Union. Two techniques, providing extrinsic rewards and behavioral management, had 
significant, positive effects, but a participative technique led to a decrease in performance.” (Welsh, Luthans, \& Sommer, 1993: 58)

Moreover, as already described above, this transfer of knowledge and teaching/ learning situation is perceived and framed in the discourse as a "battle of wills" or "mental combat," in which not only some rather different experience and knowledge stocks but also some sharply contrasting teaching and learning styles clash.

"Thus, the Agency became a political battlefield where the competing institutional logics of market rationality and bureaucratic planning collided.” (Tilczik, 2010: 1491)

All this also led to some serious criticisms of Western authors who (self-)critically diagnosed a deeply rooted misunderstanding about CEE and their citizens, particularly their managers and employees. In connection with this, Western business men are sometimes criticized for being blind about the distinctively different cultures and traditions in CEE.

"Too many American consultants and managers are failing in their efforts in Eastern Europe by misjudging Europeans' educational attainments and by ignorance of their life styles, ways of learning, management and teaching methods, and cultural values.” (McNulty, 1992: 79)

Yet, these strands of the managerial discourses do not become hegemonic in the period we have analyzed.

With respect to the construction of managerial knowledge about CEE, some rather different phases can be identified. Particularly during the early 1990s the articles were often based on mere anecdotal evidence, carrying traits of 'eyewitness accounts'. Due to the widespread knowledge deficit about CEE in Western circles any first-hand experience with CEE was gratefully welcome and readily accepted as empirical evidence.

“[T]he presence of 'state work' and 'private work' in the same company creates powerful incentives to misuse state resources. I drove for some kilometres behind a large diesel delivery truck for one of the prominent state-owned enterprises that was towing a small private car-a very unlikely official business activity. Was the driver using the truck for his personal business or fulfilling a private contract for the enterprise?” (Pearce, 1991: 83) 
Later on, researchers increasingly began to apply some rather 'classic' quantitative arms-length methods to their study of CEE economies. The studies became more and more framed along the requirements of international top-tier journals (e.g., strict methodology, quantitative surveys, and large number of interviews). Also several prominent scholars can be found among the authors of these studies, while the 'exotic outsiders' became rare. The use of qualitative, critical in-depth studies, however, continued to lag behind, and increased only slowly during the 2000s. These studies were also paralleled by a growing plea for comparative cultural studies to explain the above mentioned ambiguities and irritations relating to the supposed universalism of Western management concepts and their only limited applicability to CEE economies. 


\section{Discussion}

In our paper we have identified and described four major discursive strands of the managerial discourses about CEE, and the role images of CEE played in them. It was also highlighted that these discourses construct both images of CEE and a Western identity in one and the same discursive operation as concepts of West were present in almost every statement made about CEE economies. We have also demonstrated how different concepts and core values of IB theories, such as entrepreneurship, accountability, initiative, or competition have helped to shape these images and how they structured the images of CEE circulating in the managerial debates. Last but not least, it has also become clear that these images have mainly served as arguments to legitimate the business activities and strategies pursued by Western actors in CEE.

In more general terms, our analysis has also confirmed several important findings in the past. We found in those discourses a clear dominance of Western authors and Western arguments as already argued by other scholars (Alt \& Lang, 2004; Steger \& Lang, 2011), which only stresses that the processes of knowledge production and dissemination must be perceived as highly power-driven (Foucault, 1971). As research was found to have become more scientific but also more classical throughout the two and a half decades, it mirrors some kind of mimetic processes (DiMaggio \& Powell, 1983). Meanwhile, despite of the high dynamism of the transformation processes in CEE and a clear development path of the methodical and scientific characters of the studies observed, the overall perspective on CEE has remained rather stable over the whole period. The business experiences made in CEE during transformation obviously did not lead to a substantial renegotiation of Western managerial practices, or to a questioning of the premises and core values upon which they rested. The underlying concepts of 'deficits', 'backwardness', and 'catching up', derived from modernization theory, were - and still are - driving much of the debate. Western management concepts were not thoroughly questioned even in light of contradicting experiences and empirical evidence. Ironically enough, the very failure of Western business projects in CEE in many cases served to cement Western certainties about the validity of Western norms and the deficits of CEE culture. 
Our analysis has several implications both for IB theory and practice. In pointing out these implications several avenues for future research are also highlighted. Firstly, it provides a retrospective critical analysis of Western actors' perceptions of CEE contexts, analyzing the views of managers, firms, scholarly authors operating in this part of the world during the immediate post-Cold-War-period, when CEE economies and societies were undergoing the transition from planned to free-market economies. This stresses the importance of a historical discourse analysis that looks at the managerial discussions about CCE as integral parts of the transformation processes in and by themselves, which can help draw some lessons for academics as well as for managers and politicians.

Secondly, in reflecting the cultural embeddedness of the managerial metadiscourses on CEE, the paper critically assesses the widely unquestioned generalizability and universality of key concepts circulating in IB theory and practice, like, for example, entrepreneurship, corporate governance, incentives and accountability. These unquestioned concepts often generated questionable advice to managers and politicians, evoked misunderstandings and conflicts, and, finally, often resulted in disappointing performance of CEE businesses. Our analysis, therefore, also urges a critical perspective on the scientific analysis of transformational processes itself.

Thirdly, in analyzing the images about CEE in managerial discourses from a metaperspective, the paper problematizes the connection between overall perceptions and concrete corporate decision-making in CEE contexts. We thus argue that practices of leadership, corporate governance and CSR are to some extent defined by images about CEE and its management, while, at the same time, the decisions once taken also have an influence on the outside view on CEE business and management. Consequently, future research should dedicate more weight on the key actors, their attitudes and perceptions as well as their role and impact in transformation processes. This helps qualifying the traditional concepts of economic rationality, including rational choice and utility maximizing, in this context.

Fourthly, in identifying deep-rooted and often implicit conflicts resulting from outside views and the managerial behavior based on them, our analysis also serves to 
identify and reflect the very cultural premises of managerial action and corporate decision-making that have often been neglected by IB theory and practice in the past. In analyzing managerial discourses at the turn of the $21^{\text {st }}$ century as a historical phenomenon that was both an indicator of and factor in processes of corporate leadership and governance, we may also better comprehend the role of cultural variables in economic behavior.

Fifthly, the paper identifies language and discourse as one of the currently emerging topics in IB theory and practice, tying in with recent special issues of prominent journals in the field such as Organization Studies (Issue 1, 2004), Academy of Management Review (Issue 4, 2004), Journal of Management Studies (Issue 2, 2014), or Journal of International Business Studies (Issue 5, 2014).

Regarding implications for practice one may argue that this study is just about some nice narratives irrelevant to business operations on the ground. This opinion, however, would be misleading since the discourses observed and discussed here have some farreaching consequences for IB practice. Firstly, the constructions and interpretations described above are not just held by some scholars removed from this world but rather represent major features of the mental maps of dominant Western actors in the CEE field. Since the transformation processes in CEE can be considered a veritable power game, in which 'the winner takes all,' these constructions and interpretations become highly relevant. Secondly, these dominant views on CEE often lead to some rather questionable advices to both managers and politicians, for instance regarding what will automatically happen in CEE in the future, what concepts and instruments should be used, or how the CEE managers are to be treated. Thirdly, due to the deeply entrenched hierarchical script ('the enlightened West' vs. 'the dark East'), which most Western actors have in mind when getting involved with CEE, misunderstandings will inevitably arise and, most probably, stick. This particularly relates to the 'real' intentions and targets of the different actors, both from the West as well as from the East, involved in this process. Fourthly, clashes and conflicts are often found to be the 'logical' consequence of these perceptions and misperceptions, self-descriptions and external ascriptions. In most cases, we assume, these are rather hidden conflicts and only seldom openly expressed and communicated which, in the end, does not make them easier to 
resolve and overcome. Fifthly, images discussed above were often responsible for some disappointing results and bad performance in the end, as the vicious circle of misperceptions and prejudices led to wrong assessments about the situation Western businesses were acting in.

Our paper, of course, also bears some limitations. It is, first of all, still a relatively small sample of pieces from a wide discourse, and considerable work still needs to be done in order to refine and strengthen our findings and propositions. Furthermore, one may question why we have exactly selected this sample and not, for instance, based our analysis on books or more widespread popular media. Last but not least, our methodology may be criticized for being rather particular and, thus, focusing more on the discursive than on the practical level of what is 'really' happening in CEE. Notwithstanding these criticisms, we assume that our paper may contribute to the discussion about CEE management research by opening up a traditional 'black box' and, thus, offering some new insights into a complicated topic. 


\section{References}

Alt, R., \& Lang, R. 2004. Transformation research in East Germany: Institutions, knowledge and power. In E. Clark \& S. Michailova, S. (Eds), Fieldwork in transforming societies: Understanding methodology from experience: 114-135. Basingstoke: Palgrave.

Bachmann-Medick, D. 2009. Cultural turns: Neuorientierungen in den Kulturwissenschaften, (3rd ed.). Reinbek: Rowohlt.

Banaj, M. 1994. Preface. International Studies of Management \& Organization, 24(4): 3-4.

Beller, M., Agazzi, E., \& Calzoni, R. (Eds). 2006. Eingebildete Nationalcharaktere: Vorträge und Aufsätze zur literarischen Imagologie. Göttingen: V\&R Unipress.

Berger, P. L. \& Luckmann, T. 1966. The social construction of reality: A treatise in the sociology of knowledge. Garden City, NY: Doubleday.

Bogards, R. (Ed). 2010. Texte zur Kulturtheorie und Kulturwissenschaft. Stuttgart: Reclam.

Burke, P. 2004. What is cultural history? Cambridge: Polity.

Degtjarova, V. 2007. Russlandbilder im deutschen Fernsehen 2001-2002: Studie zur Konstruktion Russlands bei öffentlich-rechtlichen und privatrechtlichen Sendern (ARD, NDR und RTL). Hamburg : Kovač.

Depkat, V. 2003. Kommunikationsgeschichte zwischen Mediengeschichte und der Geschichte sozialer Kommunikation: Versuch einer konzeptionellen Klärung. In K.-H. Spieß (Ed), Medien der Kommunikation im Mittelalter: 9-48. Stuttgart: Steiner.

Depkat, V. 2014. Wege in die Kommunikationsgeschichte des Zeitalters der Personalunion. In S. Hölscher \& S. E. Schlitte (Eds), Kommunikation im Zeitalter der Personalunion (1714-1837). Prozesse, Praktiken, Akteure: 25-55. Göttingen: Vandenhoeck \& Ruprecht.

DiMaggio, P., \& Powell W.W. 1983. The iron cage revisited: Institutional isomorphism and collective rationality in organizational fields. American Sociological Review, 48(2): 147-160.

Dukić, D. 2012. Imagologie Heute: Ergebnisse, Herausforderungen, Perspektiven. Bonn: Bouvier.

Fischer, M. S. 1981. Nationale Images als Gegenstand vergleichender Literaturgeschichte: Untersuchungen zur Entstehung der komparatistischen Imagologie. Bonn: Bouvier.

Foucault, M. 1969. L’Archéologie du savoir. Paris: Gallimard.

Foucault, M. 1971. L'ordre du discours. Leçon inaugurale au Collège de France prononcée le 2 Décembre 1970. Paris: Gallimard.

Foucault, M. 1980. The confession of the Flesh (1977). Interview. In C. Gordon (Ed), Michel Foucault. Power/Knowledge Selected Interviews and Other Writings, 1972-1977: 194-228. Brighton: Harvester.

Gavrilova, S. 2005. Die Darstellung der UdSSR und Russlands in der Bild-Zeitung 1985-1999: Eine Untersuchung zu Kontinuität und Wandel deutscher Russlandbilder unter Berücksichtigung der Zeitungen Die Welt, Süddeutsche Zeitung und Frankfurter Rundschau. Frankfurt: Lang.

Geertz, C. 1973. The interpretation of culture. New York: Basic Books. 
Gelbuda, M., Meyer, K.E., \& Delios, A. 2008. International business and institutional development in Central and Eastern Europe. Journal of International Management, 14(1): 1-11.

Habermas, J. 1981. Theorie kommunikativen Handelns, (2 vols.). Frankfurt: Suhrkamp.

Hoffmann, J. 1986. Stereotypen, Vorurteile, Völkerbilder in Ost und West, in Wissenschaft und Unterricht: Eine Bibliographie. Wiesbaden: Harrassowitz.

Hoffmann, J. 2008. Stereotypen, Vorurteile, Völkerbilder in Ost und West in Wissenschaft und Unterricht: Eine Bibliographie: Teil 2. Wiesbaden: Harrassowitz.

Hoskisson, R.E., Eden, L., Lau, C.M., \& Wright, M. 2000. Strategy in emerging economies. Academy of Management Journal, 43(3): 249-267.

Howarth, D. R. 2000. Discourse. Buckingham: Open University Press.

Krumm, R., Medvedev, S., \& Schröder, H.-H. (Eds) 2012. Constructing identities in Europe: German and Russian perspectives. Baden-Baden: Nomos.

Landwehr, A. 2009. Historische Diskursanalyse, (2nd ed.). Frankfurt: Campus.

Lobkowicz, N. (Ed). 2008. Deutsche Rußlandbilder im 20. und 21. Jahrhundert. Köln: Böhlau.

Luhman, N. 1984. Soziale Systeme: Grundriß einer allgemeinen Theorie. Frankfurt: Suhrkamp.

Luhmann, N. 1997. Die Gesellschaft der Gesellschaft. Frankfurt: Suhrkamp.

Maurer, M. 2008. Kulturgeschichte: Eine Einführung. Köln: Böhlau.

Meyer, K.E., \& Peng, M.W. 2005. Probing theoretically into Central and Eastern Europe: Transaction, resources, and institutions. Journal of International Business Studies, 36(6): 600-621.

Mills, S. 2010. Discourse, (2nd ed.). London: Routledge.

Puffer, S. M. \& McCarthy, D. J. 2011. Two decades of Russian business and management research: An institutional theory perspective. Academy of Management Perspectives, 25(2): 21-36.

Sarasin, P. 2003. Geschichtswissenschaft und Diskursanalyse. Frankfurt: Suhrkamp.

Schütz, A. 1979/1984. Strukturen der Lebenswelt, (2 vols.). Frankfurt: Suhrkamp.

Seifert, K. 2003. Die Konstruktion Rußlands in der deutschen Auslandsberichterstattung 1985-1995: Studien zum Wandel der deutschen Wahrnehmung Rußlands. Berlin: wvb.

Soulsby, A., \& Clark, E. 2007. Organization theory and the post-socialist transformation: Contributions to organizational knowledge. Human Relations, 60(10): 1419-1442.

Steger, T. \& Lang, R. 2011. More than just Storytelling? Two Decades of Empirical Management Research on Central and Eastern Europe. Paper presented to the IACCM Conference in Rousse, Bulgaria.

Wright, M., Filatotchev, I., Hoskisson, R.E., \& Peng, M.W. 2005. Strategy research in emerging economies: Challenging the conventional wisdom. Journal of Management Studies, 42(1): 1-33.

Zacharasiewicz, W. 2010. Imagology revisited. Amsterdam: Rodopi.

Zykova, A. 2014. Zaren, Bären und Barbaren: Das mediale deutsche Russlandbild am Anfang des 21. Jahrhunderts und seine historischen Wurzeln. Herne: Schäfer. 


\section{Annex: Article Database (in chronological order)}

\subsection{Academy of Management Executive (17)}

Shaw, J. B., Fisher, C. D., \& Randolph, W. A. 1991. From maternalism to accountability: the changing cultures of Ma Bell and Mother Russia. 5(1): 7-20.

Forker, L. B. 1991. Quality: American, Japanese, and Soviet perspectives. 5(4): 63-74.

Pearce, J. L. 1991. From socialism to capitalism; the effects of Hungarian human resources practices. 5(4): 75-88.

Ivancevich, J. M., DeFrank, R. S., \& Gregory, P. R. 1992. The Soviet enterprise director: an important resource before and after the coup. 6(1): 42-55.

McNulty, N. G. 1992. Management education in Eastern Europe: 'fore and after. 6(4): 78-87.

Shama, A. 1993. Management under fire: The transformation of managers in the Soviet Union and Eastern Europe. 7(1): 22-35.

Puffer, S. M. 1994. Understanding the bear: A portrait of Russian business leaders. 8(1): 41-54.

Bruton, G. D. \& Rubanik, Y. T. 1997. Turnaround of high technology firms in Russia: The case of Micron. 11(2): 68-79.

Luthans, F. \& Riolli, L.T. 1997. Albania and the Bora Company: Lessons learned before the recent chaos. 11(3): 61-72.

Wright, M., Hoskisson, R. E., Filatotchev, I., \& Buck, T. 1998. Revitalizing privatized Russian Enterprises. 12(2): 74-85.

Rondinelli, D. A. \& Black, S. S. 2000. Multinational strategic alliances and acquisitions in Central and Eastern Europe: Partnerships in privatization. 14(4): 85-98.

Michailova, S. 2000. Contrasts in culture: Russian and Western perspectives on organizational change. 14(4): 99-112.

Puffer, S. M. \& McCarthy, D. J. 2001. Navigating the hostile maze: A framework for Russian entrepreneurship. 15(4): 24-36.

Doh, J. P., Rodriguez, P., Uhlenbruck, K., Collins, J., \& Eden, L. 2003. Coping with corruption in foreign markets. 17(3): 114-127.

May, R. C., Puffer, S. M., \& McCarthy, D. J. 2005. Transferring management knowledge to Russia: A culturally based approach. 19(2): 24-35.

Hurt, M. \& Hurt, S. 2005. Transfer of managerial practices by French food retailers to operations in Poland. 19(2): 36-49.

Farrell, D., Laboissière, M. A., \& Rosenfeld, J. 2006. Sizing the emerging global labor market: Rational behavior from both Companies and countries can help it work more efficiently. 20(4): 23-34. 


\subsection{Academy of Management Journal (12)}

Welsh, D. H. B., Luthans, F., \& Sommer, S. M. 1993. Managing Russian factory workers: The impact of U.S.-based behavioral and participative techniques. 36(1): 58-79.

Frese, M., Kring, W., Soose, A., \& Zempel, J. 1996. Personal initiative at work: Differences between East and West Germany. 39(1): 37-63.

Mueller, S. L. \& Clarke, L. D. 1998. Context and sensitivity to equity: Differences between the United States and the transition economies of Central and Eastern Europe. 41(3): 319-329.

Filatotchev, I., Buck, T., \& Zhukov, V. 2000. Downsizing in privatized firms in Russia, Ukraine, and Belarus. 43(3): 286-304.

Uhlenbruck, K. \& de Castro, J. O. 2000. Foreign acquisitions in Central and Eastern Europe: Outcomes of privatization in transitional economies. 43(3): 381-402.

May, R. C., Stewart, W. H., \& Sweo, R. 2000. Environmental scanning behavior in a transitional economy: Evidence from Russia. 43(3): 403-427.

Hitt, M. A., Dacin, M. T., Levitas, e., Arregle, J.-L., \& Borza, A. 2000. Partner selection in emerging and developed market contexts: Resource-based and organizational learning perspectives. 43(3): 449-467.

Spicer, A., Dunfee, T. W., \& Bailey, W. J. 2004. Does national context matter in ethical decision making? An empirical test of integrative social contracts theory. 47(4): 610-620.

Steensma, H. K., Tihanyi, L., Lyles, M. A., \& Dhanaraj, C. 2005. The evolving value of foreign partnerships in transitioning economies. 48(2): 213-235.

Bailey, W. \& Spicer, A. 2007. When does national identity matter? Convergence and divergence in international business ethics. 50(6): 1462-1480.

Earle, J. S., Spicer, A., \& Sabirianova Peter, K. 2010. The normalization of deviant organizational practices: Wage arrears in Russia, 1991-98. 53(2): 218-237.

Tilcsik, A. 2010. From ritual to reality: Demography, ideology, and decoupling in a postcommunist government agency. 53(6): 1474-1498.

\subsection{European Management Journal (13)}

Hermann, A. H. \& Hermann, M. 1990. Eastern and Central Europe: Opportunities and problems. 8(3): 287-290.

Kaser, M. 1990. The East European economies in transition. 8(3): 291-295.

Seddon, J. 1990. Privatization in Eastern Europe. 8(4): 500-508.

Zloch-Christy, I. 1990. Political risk assessment in lending to Eastern Europe. 8(4): 509-513.

Hünerberg, R. 1990. Risk and opportunities in Eastern Europe. 8(4): 514-519.

Manoukovsky, A. 1991. The outlook for Soviet business schools. 9(2): 182-185.

Rogers, P. \& Matthews, P. 1991. Western quality at a low price: Cleaning-up in Poland? 9(4): 425-432. 
Cummings, T., Boshyk,Y., \& Martin, C. 1992. DINA Yugoslavia 1990: Case study search for a foreign partner. 10(1): 60-73.

Randlesome, C. 1992. East German managers: From Karl Marx to Adam Smith. 10(1): 74-79.

Taucher, G. 1992. The making of the new Russian Chief Executive. 10(2): 169-172.

Beamish, P. 1992. Russki Adventures. 10(4): 465-476.

Collins, R. S. 1993. Sony in Poland: A case study. 11(1): 46-54.

Vikhanski, O., Puffer, S. M. 1993. Management education and employee twining at Moscow McDonald's. 11(1): 102-107. 